\title{
Performance Measurement in Public Sector of Transition Countries
}

\author{
Benina Veledar, Meliha Bašić, Jadranka Kapić \\ University of Sarajevo, School of Economics and Business, Bosnia and \\ Herzegovina
}

\section{Abstract}

Background: For many years, performance indicators have served as a valid instrument for the evaluation of the public sector quality and efficiency in the majority of developed countries. Such measurements allow internal and external evaluation of the efficiency of the budget and public companies. Objectives: The aim of the paper is to determine to what extent public sector entities in the Federation of Bosnia and Herzegovina (FB\&H), as a representative of transition countries, measure and report performance indicators. Methods/Approach: An electronic survey has been conducted among representatives of cantons in FB\&H and public utility companies in the Canton of Sarajevo. The Mann-Whitney test was applied in order to test differences between public sector entities according to their performance. Results: The Mann-Whitney non-parametric tests show that the degree of measuring and reporting performance indicators in the public sector in FB\&H has a direct impact on the operational results shown in financial statements. Conclusions: EU legislation encourages the development of competition between different programs, products and services in the public sector. This paper sheds light on the causes and consequences of the absence of valid performance measurement in the public sector of FB\&H and provides possible solutions to overcome identified problems within measurement, reporting and monitoring of performance indicators.

Key words: performance measurement; performance indicators; public sector; international public sector accounting standards; performance audit

JEL main category: $\mathrm{H}$

JEL classification: $\mathrm{H} 83$

Paper type: Research paper

Received: 2, July, 2013

Accepted: 30, September, 2013

Citation: Veledar, B., Bašić, M., Kapić, J. (2014), "Performance Measurement in Public Sector of Transition Countries", Business Systems Research, Vol. 5, No. 2, pp. 72-83.

DOI: 10.2478/bsrj-2014-001 1

\section{Introduction}

In most developed countries, public sector reforms have begun or have been almost implemented. In transition countries, like FB\&H, the introduction of economic laws and rules of good management with available resources is the most important and 
most difficult challenge in the reform of public management. Public sector entities deliver goods and services rather than generate profits. Therefore, their success can be only partially evaluated by information examination in their financial statements. The International Public Sector Accounting Standards Board (IPSASB) believes that the measuring and reporting of performance information about products and services being provided is necessary to meet the objectives of financial reporting by public sector entities. The practice of reporting performance information is very diverse across different jurisdictions. In some jurisdictions, public sector entities are required by law to report performance information annually, while in others, the reporting of service performance information is voluntarily and depends on entities will to enhance accountability and inform decision makers. The scope of Performance Measurement (PM) information reported, also extent of its linkage with financial statements, and the amount of detail provided also varies between jurisdictions.

This paper aims to explore whether there is a legal established system of performance measurement in the public sector of the FB\&H and which causes and consequences influence its absence. We also explore if there is voluntarily established PM system within budget users in FB\&H, on one hand, and within public companies of the Canton Sarajevo, on the other hand. Both categories are established and chaired by the State in accordance with applicable legislation, provided that public companies have certain autonomy as acting in the market by offering public goods and services. The price of their goods and services as well as reports on operations is adopted by the appropriate level of government.

The hypothesis of this research is that the degree of measuring and reporting performance indicators in public sector in FB\&H has a direct impact on the operational results shown in financial statements. Accordingly, (1) the degree of measuring and reporting performance indicators in public sector entities in FB\&H is measured by the existence of Rules on reporting product or service performance measurement information within the entity, and (2) the operational results are measured by the net profit or loss shown in income statements for public companies, and by the budget surplus or deficit shown in audit reports.

\section{Literature review}

Performance indicators are defined as indices that measure and evaluate the results of the entities, i.e. they show how well the entity achieves the stated goals and desired results (Kaplan, 2001). Performance indicators are useful for both, external and internal users, so the evaluation can be conducted as an external (conducted by the competent authorities) and internal (self-evaluation) (Melkers, Willoughby, 2005)

Measurement of performance indicators has been traditionally equated with the analysis of financial statements, which "provides the understanding of operations which are recorded in the financial statements" or "reading" the financial statements. The main deficiency is the neglect of those non-financial indicators which are heavy to measure and orientation towards the past. Therefore, the financial indicators are not often used in analyzing the operation of state entities and one of the additional reasons are limited information capabilities of their financial statements based on the accounting basis other than accrual. By combining the financial indicators with non-financial information, we get a full picture of legal entity's operations (Smith, Street, 2004). In this sense, the creation of specific indicators is adjusted with the specific requirements of management, depending on 
which activities are engaged and which non-financial information is relevant (Worthington, 2002; Bento, Ferreira White, 2006).

The importance of government unit's evaluation through a standard system of indicators is reflected in the improvement of governance because the performance indicators measure what is done (Miruć, 2010). Thereby the accountability is increased, and compliance with regulatory requirements in terms of quality and cost of services provided is enabled. Given all the previously mentioned reasons and facts, the establishment of an effective system of performance measurement is necessary (Budimir, 2007; Dražić, Dragija, 2009).

Research has shown that there are no prescribed procedures and duties of supervision over the measurement and reporting on performance indicators (lorwerth, 2006; Roje, 2007; Bajo Jakir, 2009). Since the task of monitoring is to verify the correctness of using the budget, whether it is spent for the purpose for which are they received and whether the spending was in line with the law, together with the conducting of the performance audits through the verification of the financial statements for specific year, it would be necessary to implement the performance audit (Andrić et al., 2007).

The performance audit would assess the impact to the economics, efficiency and effectiveness (the three $\mathrm{E}$ ) of the use of human, financial and other resources. One of the criteria for the implementation of the audit could be performance indicators. Performance audit would include verification of the following: (i) Has the institution defined the results and outputs to reflect the desired results of the relevant authorities?, (ii) Have defined indicators successfully set the relation of the outputs and used inputs?, (iii) Are the indicators adjusted with its primary purpose and are they sufficiently broad to provide information on most business functions of the institution?, (iiii) Do these indicators allow you assess performance in comparison to the goals, previous performance and performance of similar institutions? (Andrić et al., 2007).

Performance measurement in public sector represents a great challenge to the researchers all over the world. There are many studies on different methods for measuring the efficiency of public goods and services (Smith, Street, 2004; Miruć, 2006; Broadbent, Laughlin, 2009) and all of them provide us with different tools for improving transparency and accountability of public sector management. We can notice that as one of the key points of success in the public sector reform is performance measurement and reporting, so we decided to put this issue in focus within this research.

\section{Methodology}

For the purposes of this research, an electronic survey has been sent to representatives of 10 Cantons in Federation of Bosnia and Herzegovina and 8 public utility companies in Canton Sarajevo. Respondents were mainly financial managers and accountants. Since there is no statistical evidence on number of public companies in FB\&H, we decided to limit our analysis to the public utility companies of Canton Sarajevo. They are crucial for the functioning of Canton, both for goods and services provided, and because the amount of realized income and the number of workers they employ.

Since Sarajevo is the capital of the FB\&H and the administrative center of the Canton, it is logical that the highest amount of money flows into the budget of Canton Sarajevo, which amounted approximately to 716,5 million KM in 2011 year, making it the biggest budget in the FB\&H. Therefore, the conclusions which we make by analyzing the performance measurement in public companies of Canton 
Sarajevo will definitely give a true picture of the functioning of the other cantons in the FB\&H as well, in which the situation may be equal or even worse.

Through the survey, we analyzed whether public sector entities have developed Rules on reporting performance measurement information, whether the indicators measure the financial and non-financial performance, and whether they are the subject of performance audit. After reviewing the financial statements, as well as the most recent available audit reports (which were compiled and published by the Office for Audit of Institutions in FB\&H), and other sources of information, we found out what are the results of operations of public sector entities and if there are irregularities in their work.

\section{Results}

\section{The causes of the absence of legal PM system}

Based on analysis of the basic features of accounting and financial reporting of public sector entities, and obtained data from conducted surveys, we concluded that there is no established legal system of performance measurement in the public sector $\mathrm{FB} \& \mathrm{H}$, and the possible causes and consequences of this situation are shown below.

Research has led us to identify the most important possible causes of the absence of legal PM system in the public sector in FB\&H which are as follows:

1. Inadequate legislation relating to public sector,

2. Indifference of the responsible persons in the public sector to change the existing status quo,

3. The lack of public reaction to the alarming situation in the public sector, and

4. Little or no practice of conducting performance audits.

Under the legislation related to public sector in FB\&H, there are no provisions which oblige the budget users and public companies to implement performance measurement within their jurisdiction and to report on them, which results with the absence of responsibility for the possible bad results of operations. Therefore, performance indicators as an analytical tool for business analysis of the public sector do not officially exist in the FB\&H. In Table 1 we present research findings weather there is voluntarily established PM system within public sector entities in FB\&H.

Table 1

Rules on reporting performance measurement information within public entities in FB\&H

\begin{tabular}{|c|c|c|c|}
\hline $\begin{array}{c}\text { Usage of Rules on } \\
\text { reporting PM } \\
\text { information }\end{array}$ & $\begin{array}{c}\text { Cantons in Federation } \\
\text { of Bosnia and } \\
\text { Herzegovina }\end{array}$ & $\begin{array}{c}\text { Public utility } \\
\text { companies in } \\
\text { Sarajevo Canton }\end{array}$ & Total \\
\hline No rules on PM & 8 & 5 & 13 \\
\hline Rules on PM exist & 2 & 3 & 5 \\
\hline Total & 10 & 8 & 18 \\
\hline
\end{tabular}

Source: Author research; July 2013

Answers to questions about the existence of voluntarily established PM system showed that majority of budget users $(80 \%)$ and public companies $(62,5 \%)$ have no established Rules on reporting about PM information.

Responsible persons in the public sector are not interested for changes, so most of them during their mandate mainly deal with the consequences, but not with causes of the problem, which means keeping the status quo. This is supported by the fact 
that authorities in Sarajevo Canton usually adopt the reports on public companies operations, which make millions of losses, without detailed analysis of the causes and possible responsibility of management. It is important to find funds to cover the accumulated losses, because of the fact that public companies must exist to ensure normal development of activities in the Sarajevo Canton.

Bearing in mind the above mentioned, it is no wonder that public sector entities are reluctant to publish information on business results through websites and media. If they do that, it is usually partial information, which should be supplemented from other sources (Government, Ministries, the Office for Audit of Institutions, Official Gazettes, etc.) in order to get complete picture, and it takes a lot of time. Therefore, the service users remain uninformed about the results of operations of public sector entities and there is no reaction to the alarming situation of the public sector at the moment.

Since there is no law obligation of measuring and reporting on performance indicators in the public sector of the FB\&H, there are no prescribed procedures and obligations of supervision the mentioned indicators. Namely, although the Law on Audit of Institutions in Federation of Bosnia and Herzegovina states that: "The Audit Office has the right to review or inspect the certain aspect of the operations of all or part of the institution, program or activity in terms of economy, efficiency and effectiveness with which the institution uses its resources (performance audit)." (Official Gazette FB\&H No 22/06, Article 14), no provision obliges the Audit Office to conduct the performance audit along with the audit of financial statements, which discourages responsible individuals in the public sector to work in order to improve the economy, effectiveness and efficiency.

The results of conducted survey show that none of the observed public entities has been the subject of performance audit. The research has shown that the observed budget users are subject to external financial audit, which is conducted by the Office for Audit of Institutions in FB\&H on an annual basis. Observed companies are subject to external financial audit, which is annually conducted by the private audit companies, and in slightly longer time intervals by the Office for Audit of Institutions in FB\&H. Given that the Office for Audit of Institutions in FB\&H is limited with both, financial and human resources, in the exercise of state audit, priority have the budget and budget users, while public companies are to be audited in the periods longer than one year.

\section{The consequences of the absence of legal PM system}

Conducted research helped us to identify the possible consequences of the absence of performance indicators measurement as follows: inappropriate spending of public money; continuously increasing the losses of most public companies; and dissatisfaction of users with the quality and price of provided products and services.

After examining the most recent available audit reports of the Office for Audit of Institutions in FB\&H (July 2013, www.saifbih.ba), related to 2011 year, we noticed that 6 out of 10 cantons in FB\&H received the adverse opinion, including the Canton Sarajevo, while 4 received a qualified opinion. In most cases the budget was not sufficiently harmonized in a way that the total revenues cover the total expenses which is not adjusted to the Articles 4 and 23 of the Law on Budgets in the FB\&H (Official Gazette of FB\&H No 19/06, 76/08, 5/09), so the mentioned resulted in a total budget deficit amounting to 44.809.014 KM at the end of the year 2011 (Table 2). 
Table 2

Operational results of budget users in FB\&H measured by the budget surplus (deficit) for the years 2010 and 2011 (in KM)

\begin{tabular}{|c|c|c|c|c|c|c|}
\hline \multirow[b]{2}{*}{ Canton } & \multicolumn{3}{|c|}{2010} & \multicolumn{3}{|c|}{2011} \\
\hline & Revenues & Expenses & $\begin{array}{l}\text { Budget } \\
\text { surplus } \\
\text { (deficit) }\end{array}$ & Revenues & Expenses & $\begin{array}{l}\text { Budget } \\
\text { surplus } \\
\text { (deficit) }\end{array}$ \\
\hline $\begin{array}{l}\text { Sarajevo } \\
\text { Canton }\end{array}$ & 652.654 .214 & 674.162 .446 & -21.508 .232 & 631.056 .983 & 657.582 .266 & -26.525 .283 \\
\hline $\begin{array}{l}\text { Unsko-sanski } \\
\text { Canton }\end{array}$ & 177.217 .778 & 176.564 .036 & 653.742 & 174.565 .639 & 181.618 .064 & -7.052 .425 \\
\hline $\begin{array}{l}\text { Hercegbosanski } \\
\text { Canton }\end{array}$ & 61.647 .659 & 55.293 .335 & 6.354 .324 & 66.466 .521 & 55.396 .198 & 11.070 .323 \\
\hline $\begin{array}{l}\text { Posavski } \\
\text { Canton }\end{array}$ & 37.506 .152 & 37.441 .955 & 64.197 & 28.194 .538 & 30.577 .664 & -2.383 .126 \\
\hline $\begin{array}{l}\text { Tuzlanski } \\
\text { Canton }\end{array}$ & 310.085 .531 & 331.342 .402 & -21.256 .871 & 311.948 .153 & 325.924 .628 & -13.976 .475 \\
\hline $\begin{array}{l}\text { Srednjobosanski } \\
\text { Canton }\end{array}$ & 144.700 .417 & 146.618 .721 & -1.918 .304 & 150.776 .561 & 148.692 .030 & 2.084 .531 \\
\hline $\begin{array}{l}\text { Zapadno- } \\
\text { hercegovački } \\
\text { Canton }\end{array}$ & 74.451 .980 & 80.049 .549 & -5.597 .569 & 71.300 .286 & 73.025 .436 & -1.725 .150 \\
\hline $\begin{array}{l}\text { Hercegovačko- } \\
\text { neretvanski } \\
\text { Canton }\end{array}$ & 152.492 .941 & 163.577.455 & -11.084 .514 & 157.726 .098 & 156.697.808 & 1.028 .290 \\
\hline $\begin{array}{l}\text { Bosansko- } \\
\text { podrinjski } \\
\text { Canton }\end{array}$ & 40.437 .651 & 37.919 .774 & 2.517 .877 & 38.439 .008 & 40.463 .536 & -2.024 .528 \\
\hline $\begin{array}{l}\text { Zeničko- } \\
\text { dobojski } \\
\text { Canton }\end{array}$ & 245.306 .999 & 250.850 .852 & -5.543 .853 & 248.156 .360 & 253.461 .531 & -5.305 .171 \\
\hline Total & 1.896 .501 .322 & 1.953.820.525 & 57.319 .203 & 1.878 .630 .147 & 1.923 .439 .161 & -44.809 .014 \\
\hline
\end{tabular}

Source: Author research; July 2013

If we analyze the public utility companies we can note the following: three sample companies achieved total profit of $166.865 \mathrm{KM}$ in 2011 year which is insignificant compared to net losses of total $73.485 .700 \mathrm{KM}$ of remaining five companies (Table 3).

Table 3

Operational results of public utility companies in Sarajevo Canton measured by the net profit (loss) for the years 2010 and 2011 (in KM)

\begin{tabular}{|l|r|r|r|r|r|r|}
\hline \multicolumn{1}{|c|}{ Company } & \multicolumn{1}{|c|}{$\mathbf{2 0 1 0}$} & \multicolumn{1}{c|}{$\mathbf{2 0 1 1}$} \\
\cline { 2 - 7 } & \multicolumn{1}{|c|}{ Revenues } & \multicolumn{1}{c|}{ Expenses } & \multicolumn{1}{c|}{$\begin{array}{c}\text { Net profit } \\
\text { (loss) }\end{array}$} & \multicolumn{1}{c|}{ Revenues } & \multicolumn{1}{c|}{$\begin{array}{c}\text { Expenses profit } \\
\text { (loss) }\end{array}$} \\
\hline $\begin{array}{l}\text { Vodovod i } \\
\text { kanalizacija }\end{array}$ & 39.073 .775 & 69.487 .724 & -30.413 .949 & 36.953 .442 & 67.205 .847 & -30.252 .405 \\
\hline Sarajevogas & 110.667 .223 & 114.871 .442 & -4.204 .219 & 131.221 .040 & 135.749 .491 & -4.528 .451 \\
\hline Toplane & 56.243 .481 & 65.143 .175 & -8.899 .694 & 54.466 .816 & 72.716 .821 & -18.250 .005 \\
\hline Rad & 43.339 .934 & 43.206 .419 & 133.515 & 40.524 .284 & 40.498 .207 & 26.077 \\
\hline Park & 8.246 .230 & 8.767 .406 & -521.176 & 8.797 .375 & 9.595 .045 & -797.670 \\
\hline Pokop & 8.949 .932 & 8.932 .936 & 16.996 & 9.530 .812 & 9.520 .523 & 10.289 \\
\hline $\begin{array}{l}\text { Tržnice i } \\
\text { pijace }\end{array}$ & 4.218 .071 & 4.064 .424 & 153.647 & 4.313 .111 & 4.182 .612 & 130.499 \\
\hline Gras & 50.018 .070 & 71.755 .876 & -21.737 .806 & 47.746 .434 & 67.403 .603 & -19.657 .169 \\
\hline Total & 320.756 .716 & 386.229 .402 & -65.472 .686 & 333.553 .314 & 406.872 .149 & -73.318 .835 \\
\hline
\end{tabular}

Source: Author research; July 2013

Elements related to the sustainable management of public company should be reflected in the following indications: (1) It is expected that a public company is financially healthy in the long term, which means it is subject to ongoing market 
testing, (2) Prices charged by a public company should be based on operating costs (i.e. prices should cover marginal costs).

Previous analysis showed that the observed companies do not meet any of mentioned criteria, since even $62,5 \%$ of them realize net loss as the ultimate operations result. In order to find ways to cover the realized deficit and losses observed public entities mostly strive to increase prices, which is not accompanied by investment in the maintenance of existing infrastructure and achievement a higher level of quality services, and it results with the dissatisfaction of the customers of public goods and services. Table 4 shows descriptive statistics on operational results of public sector entities from our sample in total and also separately for budget users in FB\&H and public companies in Sarajevo Canton for the years 2010 and 2011. Average operational result for budget users in FB\&H in the year 2010 was deficit of 5.731.920,30 KM, and it decreased to deficit of 4.480.901,40 KM in 2011. Average operational result for public companies in Sarajevo Canton in the year 2010 was net loss of $8.184 .085,75 \mathrm{KM}$, and it increased to net loss of $9.164 .854,38 \mathrm{KM}$ in 2011 . At the same time, average total operational result for all public entities from the sample is similar in both years.

Table 4

Descriptive statistics on operational results of public sector entities in FB\&H for the years 2010 and 2011

\begin{tabular}{|l|l|r|r|}
\hline \multirow{2}{*}{ Public sector entity } & \multirow{2}{*}{ Indicators } & \multicolumn{1}{|c|}{$\mathbf{2 0 1 0}$} & \multicolumn{1}{c|}{$\mathbf{2 0 1 1}$} \\
\cline { 3 - 4 } & & Operational result & \multicolumn{1}{c|}{ Operational result } \\
\hline \multirow{4}{*}{ Budget users } & Mean & $-5.731 .920,30$ & $-4.480 .901,40$ \\
\cline { 2 - 4 } & $\mathbf{N}$ & 10 & 10 \\
\cline { 2 - 4 } & Std.Dev. & $9.554 .938,04$ & $1.009 \mathrm{E} 7$ \\
\hline \multirow{3}{*}{ Public companies } & Mean & $-8.184 .085,75$ & $-9.164 .854,38$ \\
\cline { 2 - 4 } & $\mathbf{N}$ & 8 & 8 \\
\cline { 2 - 4 } & Std.Dev. & $1.170 \mathrm{E} 7$ & $1.186 \mathrm{E} 7$ \\
\hline \multirow{3}{*}{ Total } & Mean & $-6.821 .771,61$ & $-6.562 .658,28$ \\
\cline { 2 - 4 } & $\mathbf{N}$ & 18 & 18 \\
\cline { 2 - 4 } & Std.Dev. & $1.031 \mathrm{E} 7$ & $1.084 \mathrm{E} 7$ \\
\hline
\end{tabular}

Source: Author research; July 2013

The hypothesis of this research is that the degree of measuring and reporting performance indicators in public sector in FB\&H has a direct impact on the operational results shown in financial statements. Accordingly, (1) the degree of measuring and reporting performance indicators in public sector entities in FB\&H is measured by the existence of Rules on reporting product or service performance measurement information within the entity, and (2) the operational results are measured by the net profit or loss shown in income statements for public companies, and by the budget surplus or deficit shown in audit reports.

In order to test this hypothesis mean values of operational results of public sector entities from the sample were calculated and put in relation to the existence of rules on reporting performance measurement information for the years 2010 and 2011 (Table 5). It was shown that public entities with rules on performance measurement achieve higher operational results for both observed years. For example, public entities with the Rules on reporting PM information had an average operational result of $1.770 .812,40 \mathrm{KM}$ in 2011, while public entities without Rules on reporting PM information had an average operational result of $-9.408 .662,46 \mathrm{KM}$ in the same year. 


\section{Table 5}

Descriptive statistics on operational results of public sector entities from the sample in relation to the existence of rules on reporting PM information for the years 2010 and 2011

\begin{tabular}{|l|l|r|r|}
\hline \multirow{2}{*}{$\begin{array}{l}\text { Existence of Rules on reporting } \\
\text { information }\end{array}$} & \multirow{2}{*}{ Indicators } & \multicolumn{2}{|c|}{ Operational result } \\
\cline { 3 - 4 } & & $\mathbf{2 0 1 0}$ & \multicolumn{1}{c|}{$\mathbf{2 0 1 1}$} \\
\hline \multirow{3}{*}{ No rules on PM exist in an entity } & Mean & $-10.008 .008,69$ & $-9.408 .662,46$ \\
\hline \multirow{3}{*}{ Rules on PM exist in an entity } & $\mathbf{N}$ & 13 & 13 \\
\cline { 3 - 4 } & Std.Dev. & $1.042 \mathrm{E} 7$ & $1.099 \mathrm{E} 7$ \\
\hline \multirow{3}{*}{ Total } & Mean & $1.462 .444,80$ & $1.770 .812,40$ \\
\hline & $\mathbf{N}$ & 5 & 5 \\
\hline & Std.Dev. & $2.745 .578,75$ & $5.304 .956,97$ \\
\hline & Mean & $-6.821 .771,61$ & $-6.303 .252,78$ \\
\hline & $\mathbf{N}$ & 18 & 18 \\
\hline & Std.Dev. & $1.031 \mathrm{E} 7$ & $1.088 \mathrm{E} 7$ \\
\hline
\end{tabular}

Source: Author research; July 2013

In order to test hypothesis, a Mann-Whitney non-parametric test was conducted (Table 6). The test results showed that there is a statistically significant difference in the following data: (i) operational result in 2010 with $1 \%$ probability (Mann-Whitney $\mathrm{U}=5,000$; $\mathrm{p}$-value $=0,007$ ); (ii) operational result in 2011 with $5 \%$ probability (MannWhitney $U=11,500 ; p$-value $=0,038$ ).

Table 6

Mann - Whitney test for the difference in operational results of sample entities in relation to the existence of rules on reporting performance measurement information

\begin{tabular}{|c|r|r|}
\hline Operational result & Mann - Whitney U & \multicolumn{1}{|c|}{$\boldsymbol{p}$ - value } \\
\hline $\mathbf{2 0 1 0}$ & 5,000 & $0,007^{*}$ \\
\hline $\mathbf{2 0 1 1}$ & 11,500 & $0,038^{* *}$ \\
\hline
\end{tabular}

Note: *statistically significant with $1 \%$ probability, **statistically significant with $5 \%$ probability Source: Author research; July 2013

Based on the conducted Mann-Whitney non-parametric tests, we can conclude that the hypothesis about existence of measuring and reporting performance indicators in public sector in FB\&H has a direct impact on the operational results shown in financial statements.

\section{Discussion and conclusion}

We can conclude that the inefficient public sector has become a limiting factor in the overall development of the FB\&H, both nationally and internationally, particularly in the context of economic integration processes. If we want to follow the path towards the European Union, we must meet the basic requirements related to the public sector reform, which are briefly included in the following items: Strengthening the accountability of public management; Identifying and application of quality standards; Measurement of the result of the activities and programs; Introduction of market mechanisms in order to reduce costs; Applying different management tools in the public sector (Denhardt, Denhardt, 2000, Barzelay, 2001).

In order to develop an effective system of performance measurement of public sector institutions in FB\&H, in accordance to the world trends, it is necessary to make certain assumptions. 
The first assumption is the introduction of program planning. Program planning allows you to measure the results of each program, to measure the cost of services provided, and to recognize the target budget users, and a successful reallocation of funds (Boyne, 2003).

The next assumption is to define the strategic and budget objectives. For quality performance measurement in the public sector institutions, it is necessary to define specific strategic goals by state government. Once you have defined strategic objectives, their value reflections are the budget target. In accordance with defined budget objectives, institutions in the public sector should define the desired results and outputs (financial plans) which will reflect the desired results set by state government (Flamholtz, 2005).

Another assumption for successful implementation of the analysis of subjects in the public sector is a reporting system adjusted to the requirements of measuring performance indicators. Prescribed financial statements are not sufficiently good basis for measuring the performance indicators of the public sector institution, but have to be adjusted in accordance with the requirements of each department (Hoogervorst, 2011). It is necessary to supplement the notes to the financial statements with all the information needed to measure performance indicators of the budget users.

The next assumption is related to the application of International Accounting Standards for public sector and transfer to the accrual basis of reporting (Vašiček, 2009). International Federation of Accountants - Public Sector Committee systemically develops and publishes the International Accounting Standards for the public sector. Those standards are complementary to International Accounting Standards for profit-oriented entities, but there are accepted specificities of the public sector. Acceptance of the International Accounting Standards for Public Sector by certain countries increases the quality and comparability of financial information provided in reports of public sector entities (Vašiček, Vašiček, Roje, 2009).

Business analysis methods designed for profit companies can not be applied in the public sector. The assumption of introducing performance measurement of budget users is also a determination of a set of quality performance indicators for each sector. Taking into account the basic characteristics of each sector, strategic and budgetary objectives and desired results and outputs to be measured, it is necessary to define a set of performance indicators as instruments of the quality and efficiency valuation of each department. When creating performance indicators, taking into account the particularities of each entity within the public sector, it is necessary to: (i) establish operational objectives (Objective) of each program, focusing on the desired results (Outcome) and the target population (Target Population) to which the program relates; (ii) determine the output values (Output) needed to achieve the desired results, (iii) determine the link between desired outcomes and output values; and (iiii) identify all resources (Input) required to produce the required output values (Bolton, 2003).

Operational objectives are derived from strategic objectives of the entity. The next step is to critically evaluate existing data on the success reported in the budgets, strategic plans and annual reports to make it possible to determine which part of the business is not necessary to change (Nicholson-Crotty, Theobald, Nicholson-Crotty, 2006). In addition, public sector entities are encouraged to constantly explore other alternative sources of useful performance indicators.

When creating performance indicators, it is necessary to consult the service users, as it improves their quality, but also encourages their acceptance by users. For the development of performance indicators, it is important to promote an organizational 
culture that puts an emphasis on getting results, self-evaluation and participation of employees. Once established performance indicators could be used, inter alia, as a management tool, which would have resulted in the following: increase efficiency; improve decision-making in the planning process; increasing transparency and accountability; achieving cost savings; improvement of services provided to users; and using resources provided in the most appropriate way (Ball, 2011, Ball, Pflugrath, 2012).

The limitation of this research regarding the relatively small number of respondents and limited timeframe should be taken into account when using its results as the basis for future actions. However, some recommendation emerged for the future research of performance measurement in public sector, such as to: (i) explore the nature of performance measurement system and its influence in other countries of SE Europe, (ii) to explore the nature of performance measurement system and its influence in EU countries (iii) to compare, analyze, propose and apply optimal PM model for FB\&H.

\section{References}

1. Andrić, M. et al. (2007). „Revizija javnog sektora“, Novi Sad: Ekonomski fakulte† Subotica.

2. Bajo Jakir, I. (2009), "Unapređenje i modernizacija proračunskih korisnika", in Vašiček, D. (ed.), Hrvatski javni sektor u aktualnim gospodarskim uvjetima, Hrvatska zajednica računovođa i financijskih djelatnika, Zagreb, pp. 25-35.

3. Ball, I. (2011), "Trust and Accountability in Public Financial Management", paper presented at CIPFA's 1st International Conference, 17 March 2011, London.

4. Ball, I., Pflugrath, G., (2012), "Government Accounting - Making Enron look good", World Economics, Vol. 13, No.1, pp. 1-18.

5. Barzelay, M. (2001). "The New Public Management, Improving Research and Policy Dialogue", Berkeley: University of California Press

6. Bolton, M. (2003), "Public sector performance measurement: delivering greater accountability", Work Study, Vol. 52, No. 1, pp. 20-24.

7. Boyne, G. (2003), "Sources of public service improvement: A critical review and research agenda", Journal of Public Administration Research and Theory, Vol. 13, No. 3, pp. 367-394.

8. Broadbent, J., Laughlin, R. (2009), „Performance management systems: A conceptual model", Management Accounting Research, Vol. 20, No 4, pp. 283295.

9. Budimir, V. (2007), "Mjerenje uspješnosti u javnom sektoru", in Vašiček, V., Vašiček, D. (eds), Hrvatski javni sektor - reforma i razvojne perspektive, Hrvatska zajednica računovođa i financijskih djelatnika, Zagreb, pp. 313-326.

10. Denhardt, R. B., Denhardt, J. V. (2000), "The New Public Service: Serving Rather then Steering", Public Administration Review, Vol. 60, No. 6, pp. 549-559.

11. Dražić Lutilsky, I., Dragija, M. (2009), „Razvoj mjerenja uspješnosti u javnom sektoru", in Vašiček, D. (ed.), Hrvatski javni sektor u aktualnim gospodarskim uvjetima, Hrvatska zajednica računovođa i financijskih djelatnika, Zagreb, pp. 221-237.

12. Bento, A., Ferreira White, L. (2006), „Budgeting performance evaluation, and compensation: A performance management model", Advances in Management Accounting, Vol. 15, No. 1, pp. 51-79.

13. Flamholtz, E. G. (2005), "Strategic organizational development and financial performance: implications for accounting, information and control", Advances in Management Accounting, Vol. 14, No. 1, pp. 139-165. 
14. Hoogervorst, H. (2011), „A time for change? The objectives of Financial Reporting", paper presented at European Commission Conference, 9 February 2011, Brussels, available at:

http://ec.europa.eu/internal_market/accounting/docs/conference20110209/sp eech_hoogervorst_en.pdf (26 July 2013)

15. Iorwerth, A. (2006), "How to Measure Government Productivity: A Review Article on 'Measurement of Government Output and Productivity for the National Accounts' (The Atkinson Report)", International Productivity Monitor, Vol. 1, No. 13, pp. 58-74.

16. Kaplan, R. (2001), "Strategic Performance Measurement and Management in Nonprofit Organizations", Nonprofit Management and Leadership, Vol. 11, No. 3, pp. 353-370.

17. Melkers, J., Willoughby, K. (2005), „Models of Performance-Measurement Use in Local Governments: Understanding Budgeting, Communication, and Lasting Effects", Public Administration Review, Vol. 65, No. 2, pp. 180-190.

18. Miruć, A. (2010), "Efficiency of Public Administration - Selected Problems", Slovenian Law Review, Vol. 7, No. 1-2, pp. 115-123.

19. Nicholson-Crotty, S., Theobald, N. A., Nicholson-Crotty J. (2006), "Disparate Measures: Public Managers and Performance-Measurement Strategies", Public Administration Review, Vol. 66, No. 1, pp. 101-113.

20. Roje, G. (2007), "Računovodstvo javnog sektora razvijenih zemalja", in in Vašiček, V., Vašiček, D. (eds), Hrvatski javni sektor - reforma i razvojne perspektive, Hrvatska zajednica računovođa i financijskih djelatnika, Zagreb, pp. 198-215.

21. Smith, P., Street, A. (2004), „Measuring the efficiency of public services: the limits of analysis", working paper, Center for Health Economics, University of York, April 2004.

22. Vašiček, V. (2009), „Računovodstvo javnog sektora u funkciji efikasnog upravljanja javnim novcem u uvjetima krize", in Drutrović, M. (ed.), Evropski put BiH u uvjetima ekonomske krize, Revicon, Neum, pp. 1-15.

23. Vašiček, V., Vašiček, D., Roje, G. (2009), "Međunarodni računovodstveni standardi za javni sektor (IPSAS) vs. Računovodstvena regulativa $u$ tranzicijskim zemljama", in Mišić, A. (ed.), Međunarodni standardi U sektoru finansija i računovodstva vs nacionalna praksa, Firkon, Mostar, pp. 139-159.

24. Worthington, A. (2002), ,Incorporating contextual information in public sector efficiency analysis: A comparative study of NSW local government", Applied Economics, Vol. 34, No. 4, pp. 453-464. 


\section{About the authors}

Benina Veledar is a PhD candidate and Senior Teaching Assistant at School of Economics and Business, University of Sarajevo, Bosnia and Herzegovina. Main research interests are Cost and Management Accounting, Budget Accounting, Financial Reporting, Financial Reports Analysis and Performance measurement in public sector. Author can be contacted at benina.veledar@efsa.unsa.ba

Meliha Bašić is associate professor at School of Economics and Business, University of Sarajevo, Bosnia and Herzegovina. Main research areas of expertise are Cost and Management Accounting, Financial Reporting, Financial Reports Analysis and Intangible Assets. Author can be contacted at meliha.basic@efsa.unsa.ba

Jadranka Kapić is associate professor at School of Economics and Business, University of Sarajevo, Bosnia and Herzegovina. Main research areas of expertise are Accounting, Budget Accounting and Accounting for Non-profit Organizations. Author can be contacted at jadranka.kapic@efsa.unsa.ba 